\title{
A Scenario-Based Program for Developing English Oral Expression Skills of Secondary Schoolers
}

\section{Walaa Hasan Mohammad Mohammad}

Prof Dr. Bahaa Eldin El-Sayed El-Naggar.

Professor of TEFL Faculty of Education ZagazigUniversity.

\section{Prof. Dr. Taher Mohammad Al-Hadi}

Professor of TEFL Faculty of Education Suez Canal University.

\section{Abstract:}

The purpose of this study was to identify and develop
some English oral expression skills for secondary
school students using a scenario-based program (SBP) in order to investigate its effectiveness in developing theirskills. The participants of the study were 30 EFL students from Al Zohour Secondary School for girls in Ismailia. The study design was quasi-experimental of one group pre-posttest. The study participants were taught the SBP which included eleven sessions developed and taught by the researcher. Data were obtained from applying an oral expression test that was administered pre and post applying the SBP. Data were then collected and analyzed statistically using t-test for paired samples, and the effect size (ES). The results of the oral expression skills test were fairly highly significant. This revealed that the developed SBP had a significantly positive effect on developing the English oral expression skills for secondary school students.

Keywords: scenarios, oral expression skills, secondary schoolers Introduction

The ultimate goal of teaching English as a foreign language is to help students be able to communicate with others. And the important point in learning English is not only to learn listening, speaking, reading and writing skills only, but to use these skills in developing communication.

Communication is deeply rooted in human behaviors and societies. It is difficult to think of social or behavioral events from which communication is absent. Indeed, communication applies to shared behaviors and properties of any collection of things, whether they are humans or not. (Wikibooks, 2013) Teaching a second or foreign language constitutes major challenges for the 
teacher of that language as teachers have to present the building blocks for the learners so that they will eventually become confident speakers in the target language. Furthermore, since second language learners conceptualize in their mother tongue, they face problems when having to use the target language. (Athiemoolam,2004)

\section{Scenarios}

According to Merriam-Webster's Learner's Dictionary online, a scenario is " a description of what could possibly happen" or "a written description of a play, movie, opera, etc.". The word "scenario" is derived from the Latin word scaena, meaning scene. (Ringland, 1998, cited in Notten: 2006). The term was originally used in the context of such performing arts as theatre and film. In the literature, there seems to be no general definition for scenario.

Scenarios are used by Blyth (2005) to refer to instruments for future in which people order their perceptions about alternatives and decisions which are made today might play out. A scenario embodies a plausible view or perception of the future in a given year linked to conditions in the present via an internally consistent sequence of events. They could be described as a road map from the present to the future. Also, Maack (2001) described scenarios as tools to look at the future through the lens of a specific issue, such as the likely outcome of a national election leading to a transfer of power or a currency devaluation. Without this grounding, there is a danger that they will be too general.

\section{Types of scenarios}

To explore the different types of scenarios, the researcher found many types which have been investigated by different researchers according to different perspectives and uses.

Nielsen,(2004) presented some types of scenario. One of them is the narrative scenario which is used as a creative tool to explore and design ideas. It is distinguished by having a structure like stories that develops around a main persona and a 
tool to support communication. Nelson added that the narrative scenario is structured like a story with a main character that is motivated to use a system in a specific situation, with a specific goal. It has two powers, the writing process power and the reading process power.

According to Errington (2008), there are some interactional scenarios that can be used in education, such as:

- Skills-based scenarios: They allow learners to demonstrate the skills they already know. Here, knowledge is applied through clear steps or procedures.

- Problem-based scenarios: They provide a problem or an issue for learners to investigate.

- Issues-based scenarios: They have different opinions as determining the best action to take.

- Speculative-based scenarios: In them, learners are presented with current knowledge and asked to consider what might happen in the future.

- Gaming-based scenarios: They use gaming approach to learning and add fun to learning, as opposed to theory based learning.

According to Di Pietro in Al Hadi (2008), there are four types of scenarios based on the roles played.

- The basic scenario/ the two role type. It is suitable for one encounter. In a group situation, there are two groups and each has a spokesperson who interacts on behalf of the whole.

- Multiple-role scenarios are useful when different direct roles are assigned to different parties where each role has a distinct reason for being involved.

- In Group scenarios, all students react in their own ways to an event or situation that involves or affects everyone in the group.

- Open-ended scenarios promote the development of long-term roles and interrelated episodes that may span a number of class actions. 


\section{Elements of good scenarios}

Many of the elements of a good scenario are similar to the elements of a good story. They include learning objectives, settings, and characters. The scenario has a lot of overlap with movie scriptwriting. We do not need to have extraordinary literary skills, instead we need rather some insight into the work being done at the learner's organization. Reality can be very compelling, so the materials for the scenario can be drawn directly from the workplace. Once the participants are engaged in the story, they will fill in any gaps that exist and even some that were not anticipated (Spero,2012). According to Comm Lab India (2016), there are some elements that must be found in scenario-based learning like a storyline and characters, questions with enough choices to allow learners to explore all possible options and take decisions and relevant feedback which provide a clear explanation of why the learner is right or wrong.

\section{Strategic Interaction}

Strategic Interaction (SI) is an approach that was structured by Robert Di Pietro based upon Vygotskian approach. According to this approach, teachers can restructure role plays found in textbook lessons to become much more effective by keeping some guidelines in mind. Lev Vygotsky encouraged social interactivity in the classroom for second language acquisition, (Carkin, 2009).

Strategic interaction, while related to the role-play, differs in a number of key respects. Emphasis is placed on authentic, meaningful scenarios that learners can relate to. This is brought about in a number of ways. The learners cannot easily predict the scenarios, as each participant does not know the goals of others. Speakers share a reason for interacting with each other, but may not share the same goals, meaning that negotiation is therefore typically required to achieve resolution, (Nicholas, 2014). Strategic interaction involves three basic stages (Rehearsal, Performance, Debriefing) that place learners into three kinds of classroom activities (small group work, paired presentations in front of the class, and whole class discussion). 
Before the activity starts, the teacher should choose or develop several conflict-based scenarios having two roles (A \& B) and develop a series of cards having a description of either Role A or $\mathrm{B}$ to be distributed to small groups. In a large class of 30 students, for example, there may be 3 separate scenarios, one for each of two small groups having 5 students each. Scenarios need to contain 4 essential elements: strategic interplay, roles, personal agendas, and shared context, (Nicholas, 2014).

\section{Oral Expression Skills}

Speaking is a neglected skill of second language learning and teaching. Teachers have taught speaking using a repetition of drills or memorization of dialogues. Speaking skills help them express themselves. There are some speaking activities to be applied to ESL and EFL classrooms. These activities include role play, simulations, information gap, brainstorming, storytelling, interviews, story completion, reporting, playing cards a picture narrating, picture describing and finding the difference. (Kayi, 2006)

Oral expression is considered to be the articulation of all the components such as the sound (vowel, consonant), stress, pause, intonation and use them in isolation and in combination and also the reception, identification, perception and development of communicative competence at the productive level. (Rathod, 2017)

Rathvon (2004) defined oral expression as "the ability to produce spoken language". Oral expression can be assessed with a variety of formats and item types, ranging from formats designed to elicit single words to pope-ended formats that allow single words to open-ended formats that permit a variety of acceptable answers. Oral expression measures include (1) word fluency (2) single-word expressive vocabulary (3) sentence completion, and (4) story retelling tasks.

O'Malley (2015) defined oral expression as people's ability to express needs, thoughts, and ideas meaningfully using appropriate syntactic, semantic, pragmatic, and phonological 
language patterns. Oral expression is important because it provides the basics for literacy development. It is essential to academic achievement in all content areas, and it is important for overall success in school. A great deal of school success is widely known for depending upon students' ability to demonstrate competency through oral communication, such as answering questions in class or participating in group discussions.

\section{Difficulties in oral expression}

English language learners need to practice language. They can do so through listening to other people that they gain their vocabulary and sentence structure. They need to listen to other people to learn the context in which words are used. Students require not only listening to others but also to be put in a safe and comfortable environment in which they can practice the skills that they have learned. (Massa, 2008)

Despite this, there are a few things that require improvement by employing a variety of theories of L2 teaching and learning. For instance, although the learners have many opportunities to use the language, they do not make significant progress in oral communication skills. The students still have problems related to limited vocabularies, collocations, structures, and pronunciation and of course fluency. Although learners are capable to communicate with their peers, they still use limited vocabularies and quite often produce inaccurate sentences structures. Furthermore, they sometimes get bored with their activities in the classroom.(Hadi, 2016)

Rabab'ah (2003) pointed out that students in Arab countries learn English in their home country where the native language is Arabic, where the only way to learn English is through formal instruction. All teachers in governmental schools are native speakers of Arabic. There is little opportunity to learn English through natural interaction in the target language which is only possible when students encounter native speakers of English who come to the country as tourists. Teachers of second or foreign language classes, however, face major challenges in their classes especially since many of their learners lack the 
confidence to communicate in the target language or to respond to questions in class. Consequently, on numerous occasions, one finds that learners sit passively in classes expecting the teacher to do most of the speaking activities. If teachers do not make a concerted effort to enable their learners to be active participants rather than passive recipients; his/her learners will be reluctant to use the target language which in this case is English. As a result, learners become disinterested, apathetic and sometimes result indisciplinary problems in the class due to communication problems. (Athiemoolam, 2004)

But for Al Hosni (2014), there are some main factors that contribute to the existence of these speaking difficulties: teachers' perceptions and tacit beliefs of teaching speaking, teaching strategies, curriculum, extracurricular activities, and assessment regulations. The study revealed that teachers believe in the importance of teaching speaking, but they do not spend enough time for that because of the shortage of time because priority is given to the coverage of the textbook topics, which emphasize teaching reading and writing rather than speaking.

\section{Oral expression activities and techniques}

The term 'techniques' refers to different classroom activities. Communicative activities, according to Wan (2017), have the following characteristics:

- They are purposeful. They are beyond strictly practicing particular structures.

- They are interactive. The activities are often conducted with others and often involve some form of discussion.

- Authentic materials are used. The situations in which the learners have to use language should be as realistic as possible. The language models given should be authentic.

- They are based on the information gap principle.

According to Iohanet (International Oral History Association) (2017), there are six types of oral communication activities: (a) One-on-One Speaking (Student-Student or StudentTeacher), (b) Small-Group or team-based oral work; (c) Full-class 
Discussions (teacher- or student-led), (d) In-Class Debates and Deliberations; (e) Speeches and Presentations, and (f) Oral Examinations. A paper by Jamshidnejad, (2011) explored how a group of language learners develop the accuracy level of their target language in oral communication, particularly when they encounter a problem. He investigated how the use of Communication Strategies (CSs) in L2 might provide opportunities to EFL language learners to collaborate together in problem solving and also to develop and practice their knowledge of the target language. The researcher employed oral communication recording as the main tool for data collection. All the sessions of the participants' group discussions were audio recorded and transcribed. Audio recording allowed him to record every word (and other audio events) during the L2 interaction between the participants.

\section{Problem of the study:}

Based on the related literature, previous studies reviewed, the researcher experience of teaching EFL, and the interviews with 15 EFL teachers, and a pilot study on EFL students in secondary schools in Ismailia, it could be claimed that oral expression is one of the difficult skills encountering those students.

\section{Questions of the study:}

The current study sought to find answers for the following questions:

- What are the oral expression skills required for first year secondary school EFL students?

- What are the features of a scenario-based program for developing oral expression skills?

- How effective is using a scenario-based program on developing oral expression skills?

\section{Hypothesis of the Study:}

There would be no statistically significant differences between the mean scores of the study group students on the pre and post oral expression skills test. 


\section{Objectives of the study:}

The present study aimed at:

- Developing English oral expression skills of first year secondary school EFL students.

- Identifying the main procedures on which a scenario-based program is emerged as a program for developing oral expression of first year secondary school EFL students.

- Measuring the effectiveness of using the scenario-based program for developing oral expression of first year secondary school EFL students.

\section{Significance of the study:}

The present study may be beneficial for the stakeholders of teaching English as a foreign language at the secondary stage as follows:

- Getting benefit from the use of scenarios for developing English oral expression skills of first year secondary school EFL students.

- Directing curriculum designers to benefit from inserting techniques based on scenarios for developing English oral expression skills of first year secondary school EFL students.

\section{Method:}

This study adopted the quasi-experimental design. The study group was dealt with as one group pre-posttest.

\section{Participants:}

The participants of the study were one class $(n=30)$ from the EFL first year secondary students of El Zohour Secondary School for Girls in Ismailia. They were treated as one group to be tested using pre-post tests. The group was taught a program based on scenarios intended to improve their oral expression skills.

\section{Instruments and materials of the study:}

- Oral Expression Skills Checklist (ORSC): It aimed at determining the most important and convenient skills to be developed for the first year EFL Language secondary students. 
The researcher reviewed the most relevant literature to the oral expression and then made a list of those convenient skills to the students learning abilities. The ORSC was judged valid and reliable by some EFL specialists, and it was concluded that there were ten oral expression skills seen required by the first year EFL secondary students. Consequently, those skills were used as a basis to the pre-post oral expression skills test. They are : (a) Expressing opinions, (b) Justifying points of view, (c) Contrasting others' claims, )d) Using linking words, (e) Explaining the same idea in different ways, (f) Making inferences, (g) Summarizing major points of talk, (h) Speaking clearly and at an understandable pace, (i) Delivering speech within a time limit, and (j) Using appropriate tone of voice.

- Oral Expression Skills Test (OEST) : The test was built mainly to measure the EFL students' performance level in the identified ten oral expression skills before and after administering the scenario-based program. The final version of the test was designed. Having judged the test valid and reliable (Reliability coefficient $=0.700$ ), it was ready to be administered to the participants concerned.

- A Scenario-Based Program (SBP) :The SBP consists of eleven sessions including an introductory session and a thank-you one. Nine sessions were about scenarios. The SBP started after the administering the pre-test. It started on February 11th and ended on April 3rd. The process of the SBP had three phases, (Rehearsal, Performance, Debriefing).These practices could give learners more opportunities to enhance their oral expression experiences, and reflect on other skills in a deeper way.

\section{Procedures:}

The researcher pre-administered the oral expression skills (OES) test. Then, she taught the scenario-based program (SBP) intended to develop English oral expression skills The SBP consisted of eleven sessions including an introductory session and a thank-you one. Nine sessions were about scenarios. It started on February 11th and ended on April 3rd, 2018. The SBP was based on the scenario process which consists of three phases, (Rehearsal, Performance, Debriefing). Those practices 
could give learners more opportunities to enhance their oral expression experiences, and reflect on other skills in a deeper way. Having concluded the SBP, the researcher postadministered the OES test. Data were collected and analyzed statistically. The results obtained were interpreted in light of the questions and the hypothesis of the study.

\section{Results and Discussion:}

Based on the statistical analysis of the present study, the study hypothesis was tested and the result was that a statistically significant difference existed between the mean scores of the study group students on the pretest and post test of the oral expression test in favor of the post test. $t$-test for independent samples was used to test this hypothesis which states that "There is no statistically significant differences between the mean scores of the study group students on the pre-test and post-test of the oral expression skills test". Mean scores, standard deviations and t-values in the pre and post administration of the oral expression skills test were computed. Table 1 shows the results.

Table 1 . $t$-test results of the study group in the pre-post administrations of the oral expression skills test (OEST)

\begin{tabular}{|c|c|c|c|c|c|c|c|c|}
\hline OEST & Measure & Mean & $\mathrm{N}$ & $\begin{array}{l}\text { Standard } \\
\text { Deviation }\end{array}$ & $\begin{array}{l}\mathrm{t}- \\
\text { value }\end{array}$ & ES & Df & Sig. \\
\hline \multirow[t]{2}{*}{ Content } & Pre & 20.10 & 30 & 2.44 & \multirow[b]{2}{*}{25.26} & \multirow{2}{*}{$\begin{array}{l}0.950 \\
\text { High }\end{array}$} & \multirow[t]{2}{*}{29} & \multirow{2}{*}{$\begin{array}{l}0.000 \\
\text { Sig. }\end{array}$} \\
\hline & Post & 26.43 & 30 & 2.79 & & & & \\
\hline \multirow[t]{2}{*}{ Delivery } & Pre & 20.07 & 30 & 1.68 & \multirow[b]{2}{*}{23.47} & \multirow{2}{*}{$\begin{array}{l}0.970 \\
\text { High }\end{array}$} & \multirow[t]{2}{*}{29} & \multirow{2}{*}{$\begin{array}{l}0.000 \\
\text { Sig. }\end{array}$} \\
\hline & Post & 26.30 & 30 & 2.15 & & & & \\
\hline \multirow[t]{2}{*}{ Total } & Pre & 40.17 & 30 & 3.71 & \multirow{2}{*}{30.53} & \multirow{2}{*}{$\begin{array}{l}0.956 \\
\text { High }\end{array}$} & \multirow[t]{2}{*}{29} & \multirow{2}{*}{$\begin{array}{l}0.000 \\
\text { Sig. }\end{array}$} \\
\hline & Post & 52.73 & 30 & 4.58 & & & & \\
\hline
\end{tabular}




\section{JRCIET}

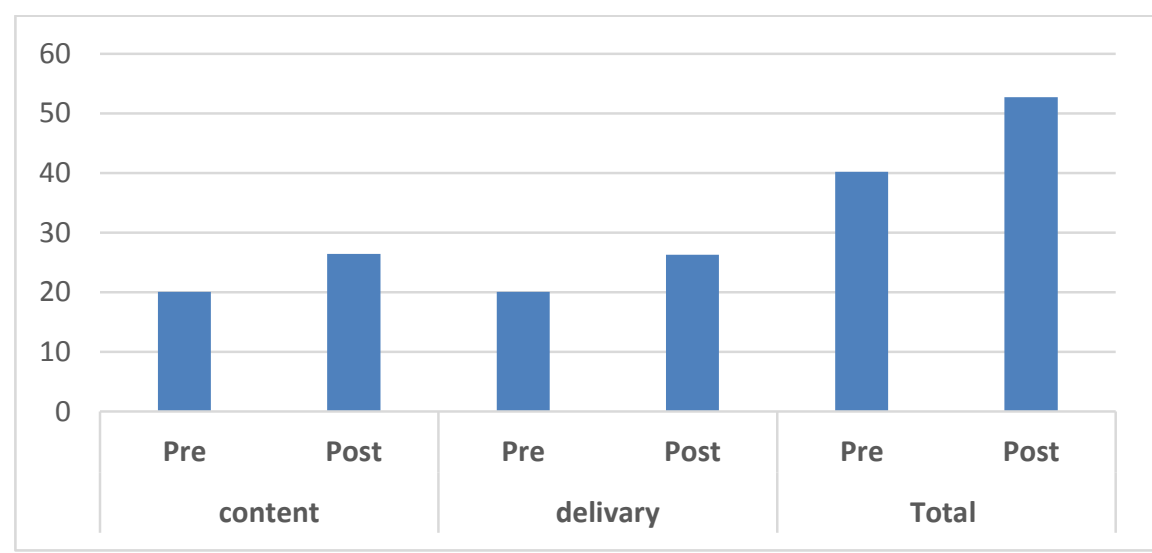

Figure 1.t-test results of the study group in the pre-post administrations of the oral expression skills (OEST) test Levels of the t-test

\section{Oral Expression Skills:}

As shown in Table 1, results indicate that the mean score of the study group in the oral expression skills pre test concerning content is 20.10 , while it is 26.43 for the same skill on the post test. For the second skill, delivery, the mean score of the pre test is 20.07. On the other hand, the mean score of the same skill on the post test is 26.30 . The mean score of the total skills as a whole of the pretest is 40.17 , while it is 52.73 for the overall pre test. Moreover, it can be noticed that t-value for the content is 25.26 , and 23.47 for the delivery skill.

In addition, there is a high significant difference between the mean scores of the pre and post administration of the test in favor of the post one as the overall t-value is 30.53 which is significant at 0,000 level. These results assure that the program was effective in developing students' oral expression skills. Such improvement might be due to having students been involved well in the learning process as the activities based on scenarios. The teacher had shown them videos which helped develop their oral expression skills. Being involved in a task to express their ideas orally, the students worked together in groups and discussed the issues presented in the videos or stories and the leader of the groups presented. Besides, students practiced 
different activities and strategies of scenario-based learning and problem-based learning as well. By practicing role-plays, students became more confident in expressing their thoughts and feelings and in communicating as whole. Also, immersing students in real life situations and problems had a great effect on their ability to persuade and convince others with their point of views. During the rehearsal phase, in which students practiced oral activities using role play, the researcher noticed that students have gained confidence in themselves while working in groups. The study participants seem to have used strategic interaction referred to by R. Di Pietro (1987) when using scenarios in their learning contexts. This might improve their abilities to think and talk. Besides, scenarios might have helped them improve their fluency

The results of the study was supported by the results of the study conducted by Leu (2013) on Chinese college students, and those reached by Yen et al. (2015) in which learners improved their speaking and writing skills through the learning tools and role-playing activities. Also, they could improve those skills via peer-to-peer and self-correction behaviors.

\section{Recommendations:}

Based on the results of the present study, it will be beneficial at this point to give some recommendations on the field of teaching English as a foreign language for both teachers and researchers:

- Teachers should plan lessons, prepare scenario-based activities, and create suitable environments to develop communicative competence of their students.

- Focusing on the role of the teacher in teaching oral expression for secondary students as the teacher's role should be changed to be facilitator and guide for students, teacher's books should demonstrate different roles for the teacher.

- Designing motivating strategies derived from scenario-based learning activities to enhance students' ability to speak in front of the class and express their ideas and feelings freely. 
- Designing real life scenarios that are more related to students' experiences and environment to get them involved in the lessons and to share them via different sources to be used in teaching oral expression.

- Training teachers to use scenario-based activities in different classes.

\section{Suggestions for Further Research:}

In light of the results of the current study, it is recommended that the following areas might be conducted in the future:

- Designing other scenario-based learning models to be used in developing the four language skills.

- Administering a study to develop oral expression skills for primary or preparatory school students using scenario-based activities.

- Investigating the use of problem-based learning to develop oral presentations for secondary stage students.

- Designing a suggested scenario-based learning program to train in-service teachers on how to teach oral expression skills.

- Further studies are needed to explore the effect of utilizing scenario-based learning activities in teaching speaking in developing students' English proficiency.

\section{References:}

Al Hosni, S. (2014). Speaking Difficulties Encountered by Young EFL Learners. International Journal on Studies in English Language and Literature (IJSELL), 2 (6),22-30. Retreived from:https://www.researchgate.net/publication/2703406 28_Speaking_Difficulties_Encountered_by_Young_EFL_Lear ners

Al-Hadi, T.M.(2008).The Use of a Scenario-Based Programme to Develop Creative Writing of EFL Post Graduate Students. The Egyptian Society Curriculum and Instruction, 11 (2), 23-56.

Athiemoolam, L.(2004). Drama-in-Education and its Effectiveness in English Second/Foreign Language Classes. The First 
International Language Learning Conference (ILLC) 2004 University Sains Malaysia, Evergreen Laurel Hotel (Penang) (16th - 18th December 2004). Retrieved March11,217 from: http:// citeseerx .ist.psu.edu /viewdoc /download? doi=10.1.1 $497.7137 \&$ rep=rep1\&type $=p d f$

Blyth, M. (2005).Learning from the future through scenario planning.[internet] Scenario Planning, 5 (3), 1-12 .

Carin, G.(2009). How 'Strategic Interaction' Can Train Better English Speakers. Retrieved from : LinkedIn website: https //www.slideshare.net/garycarkin/how-strategicinteractions-can-train-better-English-speakers

Errington, Ed (2008). Creative Learning Scenarios: A planning Guide for Adult Educators. Krieger Publishing Company, Melbourne, Reviewed by ELT Journal.

Maack, J. N. (2001). Scenario analysis: a tool for task Managers Social analysis selected tools and techniques, 62. Retrieved from:JN Maack - Social analysis selected tools and ..., 2001 - iteresources.worldbank.org

Massa, K. (2008). Storytelling as a Strategy to Increase Oral Language Proficiency of Second Language Learners. YaleNew Haven Teachers Institute. Retrieve from: http:// teachersinstitute.yale.edu/curriculum/units/2008/2/08. 02.01.x.html

Merriam-Webster Dictionary. Retrieved from: http://Merriamwebster's learnersdictionary.com/definition/scenario

Nielsen, L. (2004). Engaging Personas and Narrative Scenarios: A study on how user-centered approach influenced the perception of the design process in the e-business group at AstraZeneca. Samfundsl itteratur.

Notten, P. (2006). Scenario development: a typology of approaches. Schooling for Tomorrow: Think Scenarios, Rethink Education, 6, 66-92.

O'Malley, P.(2015). Strategies to Promote Oral Expression.

Retrieved July 27,2018, from : http :// compasse ducational services. com/ wpcontent/ Uploads/2015/07/Strategiesto-Promote-Oral Expression.pdf 
Rabab'ah, G.(2003). Communication Problems Facing Arab Learners of English. Journal of Language and Learning, 3(1), $1740-4983$

Rathod, A.(2017). Use of Videos in Developing Oral Expressions of Students. Education publishing. Retrieved from: https://books.google.com

Rathvon, N.(2004). Early Reading Assessment: A Practitioner's Handbook. Guilford Press. Retrieved from: https://books. google.com/

Scivally, A. (2013). 8 Effective Scenario Ideas for Instructional Designers. E-learning brother https :// elearning brothers .com/8-effective-scenario-ideas-for instructionaldesigners/

Wan, Y. S. (2017). Drama in Teaching English as a Second Language-A Communicative Approach. The English Teacher, 13.

Wikibooks. (2013). Communication theory. Retrieved from: https://upload.wikimedia.org/wikipedia/commons/5/51/ Communication Theory.pdf

Yen,Y., Hou , H. \& Chang, K. (2015). Applying role-playing strategy to enhance learners' writing and speaking skills in EFL courses using Facebook and Skype as learning tools: A casestudyinTaiwan. Computer-AssistedLanguage, 28(5) .ht tps: //doi.org /10.1080/09588221.2013.839568 